\title{
ANALISIS PENGARUH PERUBAHAN TEMPERATUR PANEL TERHADAP DAYA DAN EFISIENSI KELUARAN SEL SURYA POYCRYSTALLINE
}

\author{
Hasbi Assiddiq $\mathbf{S}^{1}$, Mochamad Bastomi ${ }^{2}$ \\ 1,2Jurusan Teknik Mesin Politeknik Kotabaru \\ hasbiassiddiq999@gmail.com,m.bastomi09@gmail.com
}

\begin{abstract}
ABSTRAK
Intensitas radiasi matahari merupakan sumber energi yang dikonversi oleh sel surya menjadi energi listrik, besarnya intensitas radiasi yang sampai ke permukaan bumi bervariasi pada setiap jam/hari. Adapun parameter lain yang memberikan pengaruh besar terhadap daya konversi sel surya adalah kondisi temperatur panel. Penelitian ini bertujuan; mengetahui besarnya perubahan intensitas radiasi matahari yang tiba dipermukaan bumi setiap jam/hari; mengetahui hubungan antara intensitas radiasi matahari dengan temperatur panel; mengetahui pengaruh perubahan intensitas radiasi matahari dan temperatur panel terhadap daya dan efisiensi keluaran sel surya. Pengaruh perubahan intensitas radiasi terhadap daya dan efisiensi sel surya yaitu berbanding lurus dimana pada pukul 08.00 WITA intensitas $(E) 425\left(W / m^{2}\right)$ daya keluaran $\left(P_{\text {out }}\right)$ 7,360 W dan efisiensi maksimum $\left(\eta_{m}\right)$ 9,611 \%, sedangkan pada pukul 12.00 WITA intensitas radiasi matahari $(E) 1002\left(\mathrm{~W} / \mathrm{m}^{2}\right)$ daya keluaran $\left(P_{\text {out }}\right)$ 17,03 W dan efisiensi maksimum $\left(\eta_{m}\right)$ 9,44\%. Hasil perhitungan memperlihatkan bahwa daya $\left(P_{\text {out }}\right)$ keluaran terbesar diperoleh pada temperatur panel $\left(T_{p}\right)$ terendah yaitu $36,73{ }^{\circ} C$ dengan daya $\left(P_{\text {out }}\right)$ 17,03 W dengan efisiensi maksimum $\left(\eta_{m}\right)$ tertinggi yaitu $9,44 \%$ sedangkan daya $\left(P_{\text {out }}\right)$ keluaran terkecil diperoleh pada temperatur panel $\left(T_{p}\right)$ tertinggi yaitu $45,10{ }^{\circ} \mathrm{C}$ dengan daya $\left(P_{\text {out }}\right) 14,78 \mathrm{~W}$ dan efisiensi maksimum $\left(\eta_{m}\right)$ tertinggi yaitu $8,20 \%$. Hubungan antara temperatur terhadap daya dan efisiensi maksimum berbanding terbalik.
\end{abstract}

Kata kunci: sel surya; temperatur; daya; efisiensi; intensitas

\section{ABSTRACT}

[Analysis Of The Influence Of Panel Temperature Change On Output Power And Efficiency Of Polycrystalline Solar Cell]. The Intensity of solar radiation is a source of energy that converted by solar cells into electrical energy, the magnitude of the radiation intensity that reaches the earth surface varies at every hour per day. The other parameters that gives great influence over the power of conversion power of solar cells is the temperature of the panel. The aims of this research; to find out the magnitude of changes in the intensity of solar radiation that arrives on the surface of the earth every hour/day; to find out the relationship between the intensity of solar radiation with panel temperatures; to find out the influence of changes in the intensity of solar radiation and panel temperature on the power and efficiency of solar cell output. The influence of changes in radiation intensity on the power and efficiency of solar cells was directly proportional where at 08.00 WITA the intensity (E) 425 (W/ m2) output power (Pout) $7.360 \mathrm{~W}$ and efficiency (9,) 9.611\%, while at 12.00 WITA the radiation intensity solar (E) 1002 (W/ m2) output power (Pout) $17.03 \mathrm{~W}$ and efficiency ( $\eta$ ) 9.44\%. The calculation results show that the largest output power (Pout) is obtained at the lowest panel temperature (Tp) which is $36.73{ }^{\circ} \mathrm{C}$ with a power (Pout) of $17.03 \mathrm{~W}$ with the highest efficiency ( $\eta$ ) of $9.44 \%$ while the smallest output power (Pout) obtained at the highest panel temperature (Tp) of $45.10^{\circ} \mathrm{C}$ with a power (Pout) of $14.78 \mathrm{~W}$ and the highest efficiency $(\eta)$ of $8.20 \%$. The relationship between temperature and power and efficiency is inversely proportional.

Keywords: solar cell; temperature; power; efficiency; intensity

\section{PENDAHULUAN}

Intensitas radiasi matahari sebagai sumber energi dalam penerapan sel surya, sehingga daya dan efisiensi keluarannya sangat bergantung pada perubahan radiasi. Parameter yang sangat dipengaruhi oleh radiasi matahari adalah arus (I) keluaran sel surya sedangkan pengaruhnya terhadap nilai tegangan $(V)$ cukup kecil. Radiasi matahari yang dipancarkan ke permukaan bumi hanya sebagian yang dapat sampai (direct radiation) karena sebagian telah mengalami refleksi di atmosfer (diffuse radiation). Kedua jenis radiasi tersebutlah 
yang menjadi tolak ukur dalam mengetahui besaran radiasi yang dapat diterima sel surya.

Radiasi matahari bukanlah satu-satunya parameter yang memiliki pengaruh terhadap kurva karakteristik $V-I$, namun perubahan temperatur panel juga memberikan pengaruh yang cukup signifikan. Adapun pengaruh temperatur terhadap keluaran sel surya yang cukup signifikan yaitu nilai tegangan $(V)$, sedangkan untuk arus $(I)$ pengaruhnya kecil sehingga dapat nyatakan bahwa antara pengaruh radiasi dengan temperatur terhadap daya dan efisiensi keluaran sel surya berbanding terbalik. Sel surya dapat bekerja optimal pada saat temperatur konstan yaitu $25{ }^{\circ} \mathrm{C}$. Jika temperatur sel surya meningkat di atas $25^{\circ} \mathrm{C}$, maka akan berpengaruh besar terhadap fill factor sehingga tegangan akan menurun [1].

Sumber energi matahari memiliki peran penting dalam upaya pemenuhan kebutuhan energi mengingat sumbernya sangat berlimpah. Sel surya adalah sebuah sistem pembangkit listrik alternatif ramah terhadap lingkungan yang sangat prospektif sebagai energi alternatif untuk menggantikan sistem pembangkit listrik berbahan baku energi fosil. Pembangkit listrik tenaga surya menjadi solusi untuk mengurangi ketergantungan manusia akan bahan bakar fosil untuk memenuhi kebutuhan listrik khususnya Indonesia.

Sel surya merupakan rangkaian sejumlah sel yang susun secara seri dan paralel, untuk meningkatkan tegangan dan arus yang dihasilkan sehingga cukup untuk pemakaian sistem catu daya beban. Agar maksimum energi listrik keluaran dari sel surya maksimum, maka permukaan panel harus selalu mengarah ke sudut datangnya matahari. Di Indonesia, energi listrik keluaran dari sel surya yang optimum dapat diperoleh apabila panelnya diarahkan dengan kemiringan sudut sebesar lintang lokasi pembangkit tenaga surya tersebut berada seperti yang diperlihatkan pada tabel 1 [2].

Tabel 1. Kemiringan sudut sel surya berdasarkan garis lintang

\begin{tabular}{ccc}
\hline No & Garis Lintang $\left(^{\circ}\right)$ & Sudut Kemiringan $\left(^{\circ}\right)$ \\
\hline 1 & $0-15$ & 15 \\
2 & $15-25$ & 25 \\
3 & $25-30$ & 30 \\
4 & $30-35$ & 40 \\
5 & $35-40$ & 45 \\
6 & $40-90$ & 65 \\
\hline
\end{tabular}


efisiensinya antara $14-18 \%$. Namun sel surya jenis ini juga memiliki kelemahan yakni tidak dapat berfungsi dengan baik di tempat yang kurang mendapatkan cahaya matahari (teduh), sehingga efisiensi keluarannya akan turun secara drastis dalam cuaca berawan [7]. Sel surya jenis ploikristal memerlukan luas area/permukaan yang jauh lebih besar jika dibandingkan dengan jenis monokristal agar dapat menghasilkan daya listrik yang sama. Efisiensi sel surya polikristal yang komersial lebih rendah dibandingkan jenis monokristal yakni sekitar $12-14 \%$, sehingga harganya cenderung lebih rendah [8]. Sel surya amorphous, pada sel surya jenis ini terdapat garis-garis tipis paralel pada permukaannya, garis-garis tersebut merupakan lapisan $n$ dan $p$ dari substrat silikon yang menjadi batas individu sel surya dalam panel. Sel surya ini umumnya tanpa titik hook-up atau kabel yang jelas, sehingga dapat menyulitkan dalam proses penerapannya/ penggunaannya [7].

Adapun parameter yang perlu untuk diperhitungkan dalam penerapan Sistem Pembangkit Tenaga Surya (PLTS) adalah sebagai berikut:

Faktor Pengisian/Fill Factor $(F F)$ [9]

$$
F F=\frac{V_{m} I_{m}}{V_{o c} I_{s c}}
$$

Daya Maksimum Sel Surya $P_{m}(W)$ [9]

$$
P_{m}=V_{m} \cdot I_{m}
$$

Daya Keluaran Sel Surya $P_{\text {out }}(W)[9]$

$$
P_{\text {out }}=V_{\text {oc }} \cdot I_{s c} \cdot F F
$$

Daya Masuk Sel Surya $P_{\text {in }}(W)$ [9]

$$
\begin{aligned}
P_{\text {in }}= & E \times A \\
E & =\text { Radiasi matahari }\left(\mathrm{W} / \mathrm{m}^{2}\right) \\
A & =\text { Luas permukaan sel Surya }\left(\mathrm{m}^{2}\right)
\end{aligned}
$$

Efisiensi Maksimum Sel Surya $\eta_{m}(\%)$ [9] $\eta=\frac{P_{\text {out }}}{P_{\text {in }}} \times 100 \%$

Dimana:

$$
\begin{aligned}
& F F=\text { Fill factor } \\
& V_{m}=\text { Tegangan maksimum sel Surya }(V) \\
& I_{m}=\text { Arus maksimum sel Surya }(A) \\
& V_{o c}=\text { Open Circuit Voltage }(V) \\
& I_{s c}=\text { Short } \text { Circuit } \text { Curren }(A) \\
& \eta=\text { Efisiensi sel Surya }(\%) \\
& P_{\text {out }}=\text { Daya keluaran sel Surya }(W) \\
& P_{\text {in }}=\text { Daya masukan sel Surya }(W)
\end{aligned}
$$

Sel surya bekerja berdasarkan efek fotoelektrik yang terjadi pada bahan semikonduktor untuk mengubah cahaya menjadi energi listrik. Berdasarkan teori Maxwell tentang radiasi elektromagnet, cahaya dapat dianggap sebagai spektrum gelombang elektromagnetik dengan panjang gelombang yang berbeda [10].

Gabungan antara lapisan semikonduktor jenis $p$ dan $n$ yang diperoleh dengan cara doping pada silikon murni disebut pn-junction. Pada semikonduktor jenis $p$, terbentuk hole (pembawa muatan listrik positif) yang jumlahnya lebih dominan dibandingkan jumlah elektronnya, sehingga hole merupakan pembawa muatan mayoritas, sedangkan elektron merupakan pembawa muatan minoritas. Begitupun sebaliknya dengan semikonduktor jenis $n$. Bila bagian $p$ dari $p n$ junction dihubungkan dengan kutub positif dari baterai dan bagian $n$ dihubungkan dengan kutub negatif dari baterai, maka arus akan mengalir melewati pn-junction. Keadaan itu disebut sebagai panjar maju. Bila yang dilakukan sebaliknya, maka disebut sebagai panjar mundur, yaitu bagian $n$ dari pn-junction dihubungkan dengan kutub positif dari baterai dan bagian $p$ dihubungkan dengan kutub negatif dari baterai, maka arus tidak dapat mengalir melewati pn-junction. Namun masih ada arus dalam ukuran kecil yang dapat mengalir (dalam ukuran mikroamper) disebut dengan arus bocor [11].

\section{METODE}

Penelitian/pengambilan data dilaksanakan pada bulan Agustus 2019 di Workshop dan halaman Kampus Politeknik Kotabaru Desa Stagen Kecamatan Pulau Laut Utara Kabupaten Kotabaru Propinsi Kalimantan Selatan Indonesia.

Jenis data yang digunakan dalam penelitian ini adalah data kualitatif dan kuantitatif. Data kualitatif dalam penelitian ini yaitu gambaran umum tentang pembangkit listrik tenaga surya, sejarah singkat tentang sel surya, letak lokasi penelitian. Adapun yang termasuk data kuantitatif yaitu besarnya intensitas radiasi matahari, temperatur panel, arus dan tegangan keluaran sel surya.

Sumber data pada penelitian ini yang menjadi dasar kesimpulan ada dua diantaranya adalah data primer dan data sekunder.

Untuk memperoleh data yang dikehendaki sesuai dengan permasalahan dalam penelitian ini, maka 
peneliti menggunakan beberapa metode pengumpulan data sebagai berikut:

1. Metode observasi

2. Studi dokumen

3. Studi eksperimental

4. Analisis deskriptif

Dalam penelitian ini bahan dan alat yang digunakan adalah sebagai berikut:

1. Sel surya jenis polychyrtaline model SL20TU18P $20 \mathrm{WP}$.

2. Pyranometer, tipe Solar Power Meter Tenmars TM-206.

3. Multimeter digital, Spardio SP-9205A.

4. Termokopel, Elitech dan Krisbow KW06-283.

5. Resistor keramik, 2,2 Ohm, 3,3 Ohm, 4,7 Ohm, 5,6 Ohm, 8,2 Ohm, 15 Ohm, 22 Ohm, 47 Ohm, $56 \mathrm{Ohm}$, dan $68 \mathrm{Ohm}$.

6. Switch rotary 12 posisi.

Tahap perakitan alat/system

Pada tahapan ini, semua peralatan dan bahan dirangkai hingga terintegrasi dalam suatu sistem yang dapat memberikan parameter-parameter mulai dari inputan sampai dengan keluaran sel surya.

Tahap pengambilan data

Tahapan ini, diawali dengan pengambilan data intensitas radiasi matahari $(E)$, temperatur panel $\left(T_{p}\right)$, dan tegangan $(V)$ serta arus $(A)$ keluaran sel surya pada setiap jam/hari.

Tahap analisa hasil dan evaluasi

Pada tahap ini, dilakukan proses perhitungan dengan menggunakan persamaan yang telah disajikan pada teori dasar/pendukung agar dapat mengetahui pengaruh temperatur panel terhadap daya dan efisiensi keluaran sel surya polychrytaline $20 \mathrm{WP}$.

\section{HASIL DAN PEMBAHASAN}

Data hasil pengamatan dan pengujian di Gedung dan halaman Kampus Politeknik Kotabaru akan dihitung menggunakan persamaan yang telah disebutkan pada bagian 1.2 untuk mengetahui pengaruh perubahan temperatur panel terhadap daya dan efisiensi keluaran sel surya jenis Polycristaline. Adapun data yang dijadikan sebagai contoh perhitungan dari hasil pengujian digunakan data maksimum pada pukul 12.00 WITA adalah sebagai berikut:

Luas sel surya $(A) \quad=0,50 \times 0,36=0,18 \mathrm{~m}^{2}$
Intensitas radiasi matahari $(E)=1002 \mathrm{~W} / \mathrm{m}^{2}$

Arus hubung singkat $\left(I_{s c}\right) \quad=1,11 \mathrm{~A}$

Tegangan hubung terbuka $\left(V_{o c}\right)=21,20 \mathrm{~V}$

Arus maksimum $\left(I_{m}\right) \quad=1,02 \mathrm{~A}$

Tegangan maksimum $\left(V_{m}\right) \quad=16,70 \mathrm{~V}$

Faktor Pengisian $F F$

$$
\begin{aligned}
F F & =\frac{V_{m} \times I_{m}}{V_{o c} \times I_{S c}} \\
& =\frac{16,70 \times 1,02}{21,20 \times 1,11} \\
& =0,724
\end{aligned}
$$

Daya Maksimum Sel Surya $P_{m}(W)$

$$
\begin{aligned}
P_{m} & =V_{m} \times I_{m} \\
& =16,70 \times 1,02 \\
& =17,03 \mathrm{~W}
\end{aligned}
$$

Daya Keluaran Sel Surya $P_{\text {out }}(W)$

$$
\begin{aligned}
& P_{\text {out }}=V_{\text {oc }} \times I_{s c} \times F F \\
&=21,20 \times 1,11 \times 0 \\
&=17,03 \mathrm{~W} \\
& \text { aya Masuk Sel Surya } P_{\text {in }} \\
& r_{\text {in }}=E \times A \\
&=1002 \times 0,18 \\
&=180,36 \mathrm{~W}
\end{aligned}
$$$$
=21,20 \times 1,11 \times 0,724
$$

Daya Masuk Sel Surya $P_{i n}(W)$

Efisiensi Maksimum Sel Surya $\eta_{m}(\%)$

$$
\begin{aligned}
\eta_{m} & =\frac{P_{m}}{P_{i n}} \times 100 \% \\
& =\frac{17,03}{180,36} \times 100 \% \\
& =9,44 \%
\end{aligned}
$$

Dari hasil perhitungan menunjukkan bahwa intensitas radiasi matahari $(E)$ sangat besar pengaruhnya terhadap daya keluaran $\left(P_{\text {out }}\right)$ dan efisiensi maksimum $\left(\eta_{m}\right)$ keluaran dari sel surya. Berdasarkan hasil pengamatan dan analisis menunjukkan bahwa pada pukul 08.00 WITA intensitas $(E) 425\left(\mathrm{~W} / \mathrm{m}^{2}\right)$ daya keluaran $\left(P_{\text {out }}\right)$ yang diperoleh sebesar 7,360 $\mathrm{W}$ dan efisiensi maksimum $\left(\eta_{m}\right)$ yang diperoleh adalah 9,611 \%, sedangkan pada pukul 12.00 WITA intensitas radiasi matahari $(E)$ $1002\left(\mathrm{~W} / \mathrm{m}^{2}\right)$ daya keluaran $\left(P_{\text {out }}\right)$ yang diperoleh sebesar 17,03 $W$ dan efisiensi maksimum $\left(\eta_{m}\right)$ yang diperoleh yaitu 9,44\%. Namun pada pukul 16.00 WITA semua data hasil pengamatan kembali menurun dimana intensitas radiasi matahari $(E) 395$ $\left(W / \mathrm{m}^{2}\right)$ daya keluaran $\left(P_{\text {out }}\right)$ yang diperoleh sebesar $7,421 W$ dan efisiensi maksimum $\left(\eta_{m}\right)$ yang diperoleh yaitu $10,429 \%$. Hal tersebut juga diperlihatkan pada gambar 2 grafik hubungan antara radiasi matahari $(E) \mathrm{W} / \mathrm{m}^{2}$ terhadap daya keluaran $\left(P_{\text {out }}\right)$ dan efisiensi maksimum $\left(\eta_{m}\right)$ keluaran sel 
surya polycristaline. Perubahan intensitas cahaya mempengaruhi efisiensi dari sel surya, apabila intensitas cahaya diperbesar maka efisiensinya akan meningkat [8].

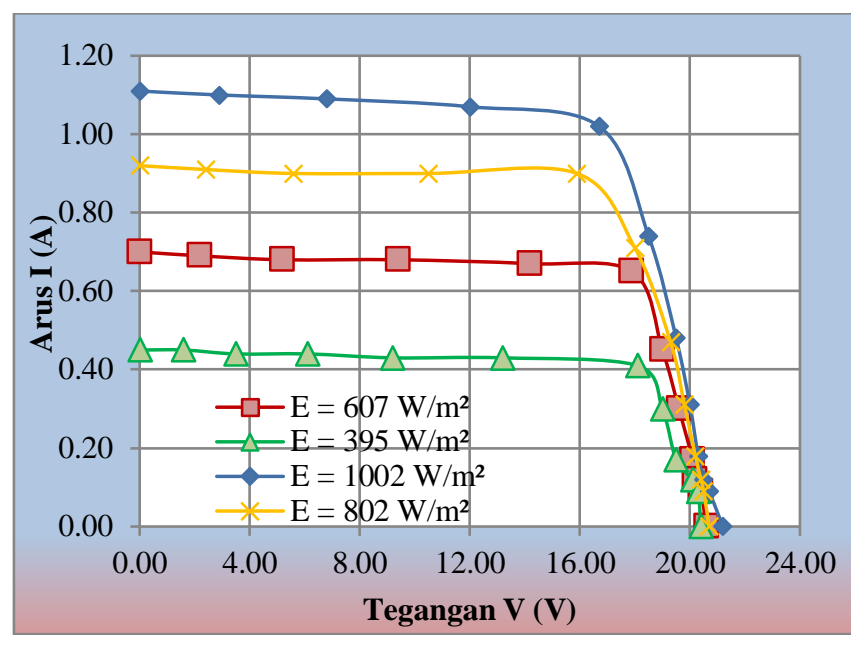

Gambar 1. Grafik hubungan antara intensitas radiasi matahari $(E)$ terhadap daya keluaran $\left(P_{\text {out }}\right)$ dan efisiensi maskimum $\left(\eta_{m}\right)$ keluaran sel surya polycristalline

Hasil pengujian secara eksperimental memperlihatkan bahwa besarnya temperatur panel sangat mempengaruhi tegangan $(V)$ dan arus (I) keluaran sel surya polycristaline. Selain intensitas radiasi matahari, temperatur panel juga sangat mempengaruhi daya konversi energi matahari dari sel surya jenis polycristaline seperti yang telah diperoleh di dalam penelitian ini yang diperlihatkan pada gambar 3 grafik hubungan antara temperatur panel $\left(T_{p}\right)$ terhadap tegangan $(V)$ dan arus $(I)$ keluaran sel surya polycristaline di bawah ini, data tersebut diperoleh pada kondisi intensitas radiasi yang sama yaitu $1002 \mathrm{~W} / \mathrm{m}^{2}$. Temperatur panel memberikan pengaruh terhadap kinerja sel surya polycristaline khususnya pada tegangan keluarannya, dari hasil pengujian dan pengamatan memperlihatkan pada saat temperatur panel rendah maka tegangan keluaran yang diperoleh besar. Begitupun sebaliknya bila temperatur panel tinggi maka tegangan keluaran dari sel surya jenis polycristaline akan menjadi kecil, sehingga dapat diasumsikan bahwa hubungan antara temperatur dengan tegangan yaitu berbanding terbalik. Kenaikan temperatur pada permukaan panel surya dapat menurunkan besar daya listrik yang diprosuksi serta juga dipengaruhi oleh bahan silikon sel surya yang mampu menyerap energi foton sekaligus panas dari radiasi matahari [6].

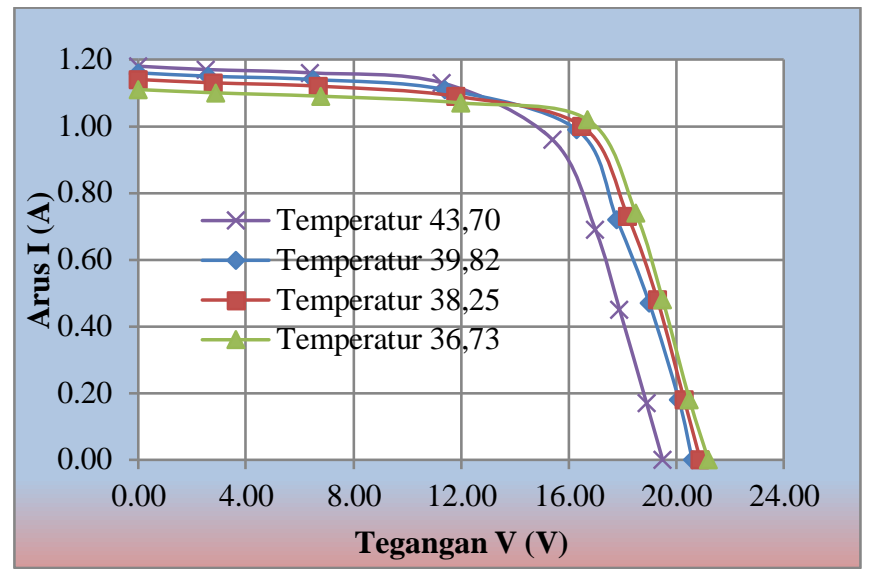

Gambar 2. Grafik hubungan antara temperatur panel

$\left(T_{p}\right)$ terhadap terhadap tegangan $(V)$ dan arus $(I)$ keluaran sel surya polycristaline

Dari hasil pengamatan memperlihatkan bahwa hubungan antara waktu penyinaran matahari yang datang ke permukaan bumi terhadap perubahan temperatur panel sel surya jenis polycristaline berbanding lurus yang terjadi pada pukul 08.00 WITA hingga pukul 12.00 WITA, namun kembali berbanding terbalik yang terjadi pada pukul 13.00 WITA hingga pukul 16.00 WITA dimana temperatur maksimum diperoleh pada saat intensitas radiasi matahari terbesar $1002 \mathrm{~W} / \mathrm{m}^{2}$ yaitu $45,10{ }^{\circ} \mathrm{C}$ seperti yang diperlihatkan pada gambar 4. Intensitas matahari mempengaruhi besar daya, dimana bila intensitas rendah daya yang dihasilkan rendah sedangkan intensitas tinggi daya yang dihasilkan akan naik pula [4].

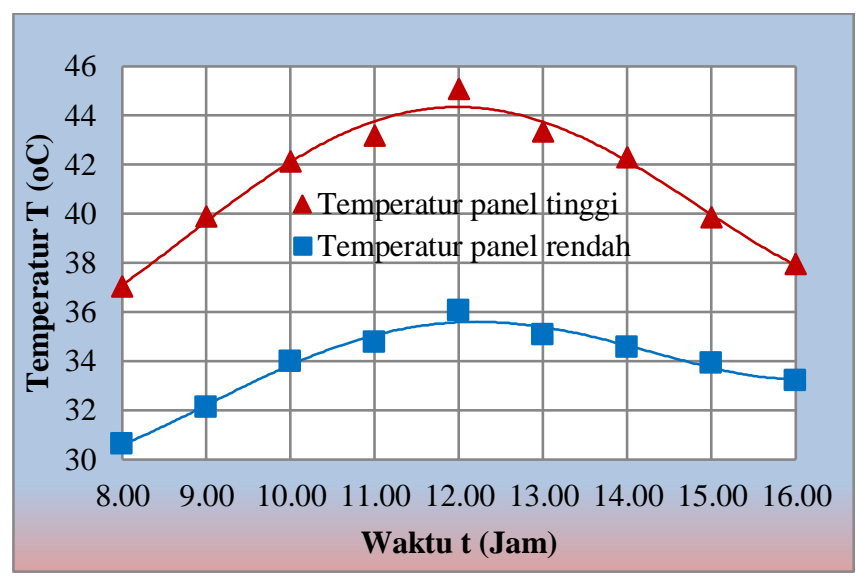

Gambar 3. Grafik hubungan antara perubahan waktu penyinaran matahari terhadap temperatur panel sel surya jenis polycristaline 
Data yang diperoleh memperlihatkan bahwa daya $\left(P_{\text {out }}\right)$ keluaran terbesar pada temperatur panel $\left(T_{p}\right)$ terendah yaitu $36,73{ }^{\circ} \mathrm{C}$ dengan daya $\left(P_{\text {out }}\right) 17,03 \mathrm{~W}$ dengan efisiensi maksimum $\left(\eta_{m}\right)$ tertinggi yaitu 9,44 $\%$ sedangkan daya $\left(P_{\text {out }}\right)$ keluaran terkecil diperoleh pada temperatur panel $\left(T_{p}\right)$ tertinggi yaitu $45,10{ }^{\circ} \mathrm{C}$ dengan daya $\left(P_{\text {out }}\right) \quad 14,78 \quad W$ dengan efisiensi maksimum $\left(\eta_{m}\right)$ tertinggi yaitu $8,20 \%$.

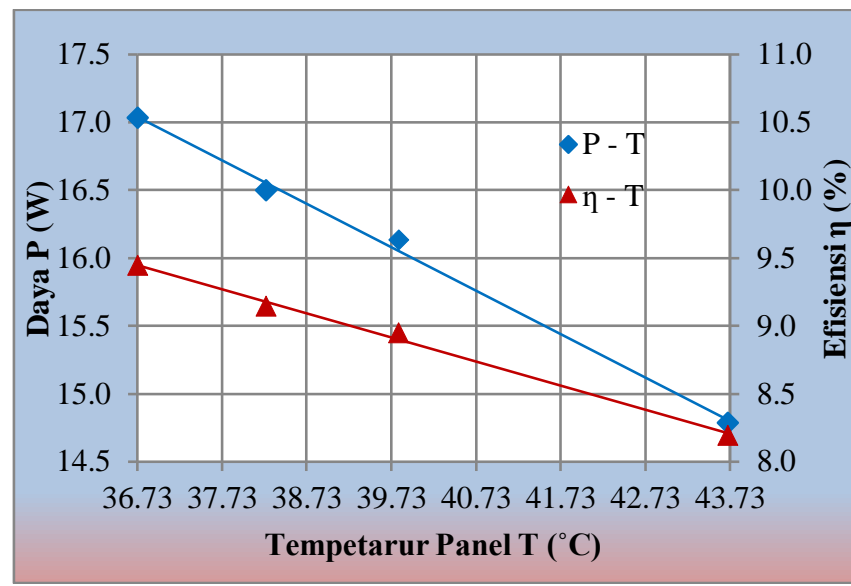

Gambar 4. Grafik hubungan antara temperatur panel

$(T)$ terhadap daya $\left(P_{\text {out }}\right)$ dan efisiensi maksimum

$\left(\eta_{m}\right)$ keluaran sel surya jenis polycristaline

Hubungan antara temperatur terhadap daya keluaran yaitu berbanding terbalik karena apabila temperatur panel semakin tinggi maka daya keluaran dari sel surya semakin kecil begitupun sebaliknya bahwa semakin rendah temperatur panel maka semakin besar pula daya keluaran dari sel surya jenis polycristaline seperti yang diperlihatkan pada gambar 5. Semakin besar temperatur panel surya maka akan terjadi penurunan produksi listrik khususnya pada tegangan keluaran [5].

\section{KESIMPULAN}

Intensitas radiasi matahari memberikan pengaruh besar terhadap daya dan efisiensi keluaran sel surya memberikan pengaruh yaitu pada saat intensitas $(E)$ $425\left(\mathrm{~W} / \mathrm{m}^{2}\right)$ daya keluaran $\left(P_{\text {out }}\right)$ yang diperoleh sebesar 7,360 $\mathrm{W}$, sedangkan pada intensitas radiasi matahari $(E) 1002\left(\mathrm{~W} / \mathrm{m}^{2}\right)$ daya keluaran $\left(P_{\text {out }}\right)$ yang diperoleh sebesar 17,03 W.

Temperatur panel memberikan pengaruh terhadap kinerja sel surya polycristaline khususnya pada tegangan $(V)$ keluarannya, hasil pengujian dan pengamatan memperlihatkan pada saat temperatur panel rendah maka tegangan keluaran yang diperoleh besar.

\section{DAFTAR PUSTAKA}

[1] Y. Gunardi, "PERANCANGAN DAN PEMBUATAN PEMBANGKIT LISTRIK TENAGA MATAHARI UNTUK LAMPU PENERANGAN JALAN.pdf," J. Sinergi, vol. 14, no. 1, pp. 63-68, 2010.

[2] A. Rahayuningtyas, "Studi Perencanaan Sistem Pembangkit Listrik Tenaga Surya (Plts) Skala Rumah Sederhana Di Daerah Pedesaan Sebagai Pembangkit Listrik Alternatif Untuk Mendukung Program Ramah Lingkungan Dan Energi Terbarukan," Pros. ANaPP Sains, Teknol. dan Kesehat., pp. 223-230, 2014.

[3] H. Assiddiq S, S. Himran, and Jalaluddin, "ANALYSIS IMPROVED EFFICIENCY OF PHOTOVOLTAIC CELLS WITH THE USE OF COOLING WATER FLOW ON THE BOTTOM PANEL," Hasanuddin University, 2014.

[4] S. Yuliananda, G. Sarya, and R. R. Hastijanti, "Pengaruh perubahan intensitas matahari terhadap daya keluaran panel surya," J. Pengabdi. LPPM Untag Surabaya, vol. 01, no. 02, pp. 193-202, 2015.

[5] D. Suryana, "Pengaruh Temperatur/Suhu Terhadap Tegangan Yang Dihasilkan Panel Surya Jenis Monokristalin (Studi Kasus: Baristand Industri Surabaya)," J. Teknol. Proses dan Inov. Ind., vol. 1, no. 2, pp. 5-8, 2016.

[6] K. Hie Khwee, "Pengaruh Temperatur Terhadap Kapasitas Daya Panel Surya (Studi Kasus: Pontianak)," J. ELKHA, vol. 5, no. 2, pp. 23-26, 2013.

[7] F. Afifudin and F. S. Hananto, "Solar Cell Menggunakan Lensa Pemfokus," Neutrino, vol. 4, no. 2, pp. 1-14, 2012.

[8] R. Magrissa, "Pengaruh Intensitas Cahaya terhadap Efisiensi Sel Solar pada MonoCrystalline Silikon Sel Solar Abstrak," pp. 
$1-12$.

[9] S. A. Kalogirou, Solar Energy Engineering Processes and Systems. America, 2009.

[10] R. Subarkah and B. Belyamin, "Pemanas Air Energi Surya Dengan Sel Surya Sebagai Absorber," Poli-Teknologi, vol. 10, no. 3. pp. 225-231, 2011.

[11] P. K. Dash and N. C. Gupta, "Effect of Temperature on Power Output from Different Commercially available Photovoltaic Modules," J. Eng. Res. Appl. www.ijera.com, vol. 5, no. 1, pp. 148-151, 2015. 